\title{
Jurisdição e Judiciário: um estudo a partir do pensamento de Hannah Arendt
}

\section{Luiz Fernando Castilhos Silveira*}

"Eles estão tão fascinados pela coerência do seu sistema e tornamse assassinos porque estão prontos a tudo sacrificar por essa coerência, por esse 'belo' autofechamento."

Hannah Arendt, Vies Politiques (Paris, 1974), p.152.

"O que proponho é simples: trata-se apenas de refletir sobre o que estamos fazendo."

Hannah Arendt, A Condição Humana.

\section{INTRODUÇÃO}

O presente trabalho tem por escopo uma análise - ainda que breve - do papel desempenhado pelo processo judicial (e especialmente pelo Processo Civil) na sociedade contemporânea. Ante a complexidade e pluralização das relações sociais atuais, o paradigma filosófico racional já não apenas sinaliza seu esgotamento, mas lateja sua completa inadequação como fundamento de teorias sociopolíticas. Na mesma esteira, a ideologia político-liberal segue atrelada ao Judiciário, no melhor estilo laissezfaire $^{1}$ que contradiz um esforço de con-

\footnotetext{
* Professor em Ciências Jurídicas e Sociais na UFRGS; mestre em Direito pela UNISINOS. Advogado militante. silveira@snbadvogados.com.br

1 Como um Judiciário que, pelos mais diversos motivos, se abstém de julgar, seja protelando a decisão "por culpa do excesso de recursos ou de trabalho", seja atribuindo-a a outrem (lei, princípios, legislador, etc.). Bem mencionou Ovídio Baptista: "[p]ara o pensamento conservador, manter o status quo é o modo de não ser ideológico. $\mathrm{O}$ magistrado que indefere a liminar pedida pelo autor não imagina que esteja outorgando, diríamos, uma 'liminar' idêntica ao demandado, apenas de sinal contrário, enquanto idêntico benefício processual, permitindo que ele continue a desfrutar do status quo a custo zero." Quanto
} 
cretização de um Estado democrático de direito constitucionalmente previsto.

Os problemas que se põem são muitos. O presente texto pretende abordar uma concepção que vise ao fortalecimento do Poder Judiciário como instituição integrante da democracia nacional (em um sentido diferente da mera aplicação literal de uma Lei heterônoma), focando diretamente a questão da legitimidade do julgador. John Merryman $^{2}$ alertara do papel desempenhado pelo juiz na tradição do Direito Continental: a de um servidor público, um funcionário. E como tais os magistrados são reconhecidos e respeitados. ${ }^{3}$

Entretanto, essa não é a única forma de se conceber o Judiciário - e essa concepção de julgador deveria estar tão desgastada quanto o próprio paradigma em que se insere. Há maneiras de o juiz não ser nem o burocrata ${ }^{4}$ que aplica as diretrizes de um 'governo de ninguém' ${ }^{5}$ nem alguém que impõe as suas próprias verdades com arbitrariedade pura - velada ou exposta. É via correlata ao que Ovídio Baptista ${ }^{6}$ classificou como "resgatar a figura do juiz responsável - oposto ao juiz do sistema, que não comete injustiças."

Esse caminho passa pela negação do esvaziamento do magistrado enquanto relevante para a operacionalização do Direito. É preciso esquecer a figura da separação absoluta dos poderes, como idealizada pela doutrina

à atribuição da responsabilidade a outrem, segue o doutrinador: "[s]e o juiz aplicar a vontade da lei, imagina-se que a injustiça terá sido cometida pelo legislador." Cf. SILVA, Ovídio A. Baptista da. Processo e Ideologia. Rio de Janeiro: Forense, 2006, p.16.

2 MERRYMAN, John. La Tradición Jurídica Romano-Canônica. México: Fondo de Cultura Económica, 1971.

3 Ibidem, p.67, 72 et passim.

4 Com relação à perda da legitimidade do juiz pela sua insersão no 'poder burocrático, ver, dentre outros, SILVA, Ovídio A. Baptista da. Processo e Ideologia. Rio de Janeiro: Forense, 2006, p.45.

5 Hannah Arendt se referiu à burocracia como o "mando de ninguém", ou seja, uma operacionalização em que ninguém se torna responsável. A autora considera, justamente por isso, que talvez seja a forma menos humana e mais cruel de governo. ARENDT, Hannah, Responsabilidade e Julgamento. Trad. Rosaura Eichenberg. São Paulo: Companhia das Letras, 2004, p.94; (Cf. Infra).

6 SILVA, Ovídio A. Baptista da. Fundamentação das Sentenças como Garantia Constitucional, in Revista do Instituto de Hermenêutica Jurídica, vol. 1, n.4. Porto Alegre: Instituto de Hermenêutica Jurídica, 2006, p.323-352.

7 Ibidem, p.333. Nesse sentido, será trabalhado no decorrer do texto a questão da responsabilidade dos julgadores, tanto no sentido pessoal quanto coletivo, a partir das idéias de Hannah Arendt. Também será revista a questão dessa impossibilidade de perceber injustiças a partir dessa mesma matriz teórica, o que, para a autora, está entre as origens do sistema totalitário ( $C f$. Infra). 
francesa da era moderna, em que o Judiciário é um poder nulo, a mera boca da lei. ${ }^{8}$ E ninguém mais apto a por essa mudança em escopo que os próprios julgadores, com apenas um cuidado: não transformarem um totalitarismo da verdade burocrática (elaborada sob critérios de eficiência moderna) em um totalistarismo de suas 'verdades' e convicções pessoais ou corporativas.

Dentro dessa perspectiva, o que deve conferir legitimidade ao Judiciário e prestígio aos juizes é precisamente o papel democrático que estes podem desempenhar, assumindo o debate político, ${ }^{9} \mathrm{em}$ vez de fingir que o mesmo, para eles, sequer existe. Busque-se a operacionalização do jurídico da forma mais adequada a uma democracia tão almejada - uma que não seja disfarce a qualquer oligarquia governante, a qual impõe seus valores e soluções aos demais cidadãos -, que esteja compromissada com o respeito à diversidade inerente ao regime democrático. ${ }^{10} \mathrm{Um}$ passo além de identificar o problema, este estudo pretende pôr um caminho para discussão.
O enfoque que se propõe, com vistas a despertar um espírito de reflexão e movimento em busca de solução ao problema, se desenvolverá a partir do pensamento de Hannah Arendt. Tomando-se como referência alguns conceitos centrais da autora, como, principalmente, 'verdade', 'espaço público', 'senso comum', 'responsabilidade', 'mal radical' e 'banalidade do mal', além de alguns de seus insights acerca das origens do totalitarismo, pretende-se questionar essas idéias de forma a tencionar uma possível interpretação do direito processual a partir desse enfoque e suas conseqüências.

Este texto se dividirá em duas partes. Na primeira, apresentar-se-á brevemente alguns conceitos arendtianos que se consideram centrais para a compreensão do argumento que se pretende desenvolver. No segundo momento, pretende-se relacionar o pensamento da filósofa com algumas características de nosso Processo Civil, tomando-se como referência a visão de alguns juristas que possuem relevantes

8 Cf. MERRYMAN, Op. Cit., p.37, ss. et passim; Cf. também MATEUCCI, Nicola. Organización del Poder y Libertad: historia del constitucionalismo moderno. Madrid: Trotta, 1998, passim.

9 Por 'debate político' não se quer qualquer concepção restrita, como um debate políticopartidário; Entenda-se como o debate respeitante à administração do poder, da república (Res Publica, bem comum, etc.); toma-se, principalmente, o termo 'político' no sentido arendtiano (Cf. Infra).

10 Cf. SILVA, Ovídio A. Baptista , da. Fundamentação das Sentenças..., passim.; sobre a crise de legitimidade da democracia causada pela forma racionalista de conceber o Direito, ver SILVA, Ovídio A. Baptista da. Processo e Ideologia (Cit.), p.56; sobre a questão da diversidade versus 'pasteurização' do regime democrático como uma sociedade de 'iguais', ver MATEUCCI, Nicola. Op.Cit., p.255 et passim. 
contribuições críticas ao estudo do tema, como John Merryman, Mauro Capeletti e Ovídio Baptista.

Por mais que a primeira parte pareça um tanto afastada ou desconectada com o tema que está sendo tratado (processo e jurisdição), pede-se que o leitor não se deixe enganar. Talvez as críticas mais severas e contumazes se encontrem justamente ali, nas entrelinhas. A estrutura do presente texto não é casual e visa a permitir que quem tome contato com ele possa, no decorrer da leitura, tirar suas próprias conclusões, ter seus próprios insights para, na segunda parte, poder confrontá-los com alguns dos que serão apresentados. Já na primeira parte do texto, pretende-se deixar que o intérprete busque a relação com o tema, e pistas que levem a essas conecções serão oferecidas ao seu sabor. Essa primeira parte tampouco se presta a uma exposição exaustiva do pensamento arendtiano, mas visa apenas a expor alguns poucos conceitos que parecem centrais para algumas reflexões na área da jurisdição.

Saliente-se que o presente trabalho não se presta a uma mera análise do que é ou foi o processo judicial; tampouco visa a descrever o que ele deveria ser, em termos absolutos - e isso, principalmente, porque se acredita, com a companhia de Ovídio Baptista (dentre outros), que não há ciência do processo - perfeita, acabada, ideal e a-histórica.
Pelo contrário, reconhece-se a proposta aqui exposta como utópica, como uma tensão com o intuito de demonstrar que o processo, tal como concebido hoje, não mais se presta à sociedade pós-segunda guerra (para a qual serve, com imenso propósito e não ao acaso, o pensamento arendtiano). Não se quer instituir uma verdade por outra: lembremos que Arendt toma qualquer ditadura da verdade como tão tirânica quanto qualquer outra forma de despotismo. ${ }^{11}$

O objetivo, por fim, é o deslocamento do discurso do processualismo tradicional, com vistas a identificar problemas e tencionar soluções que possam ser adequadas a uma realidade (sempre) transformada.

\section{BREVE EXPOSIÇÃO DE ALGUMAS IDÉIAS DE HANNAH ARENDT}

Esta autora desempenha um papel central na filosofia política do pósguerra, não sendo de se desconsiderar, dentre as razões, sua origem judaica e alemã. Tendo presenciado em terras germânicas a tomada do poder por Hitler, em 1933, e o surgimento do terceiro Reich, Arendt fugiu da Alemanha nazista para Paris e, após novos problemas políticos decorrentes da guerra (por ser nacional de um inimigo da França), conseguiu escapar para os Estados Unidos em 1941.

11 ARENDT, Hannah. Verdade e Política. Trad. Manuel Alberto. Lisboa: Relógio d’Água Editores, 1995, p.35. 
Tais acontecimentos levaram o pensamento arendtiano a uma guinada considerável. A autora não perdeu suas influências existencialistas adquiridas pelos estudos com Jaspers e Heidegger, mas cambiou seu foco prinicipal para a relação entre a filosofia que lhe era imanente e a política, principalmente no que toca aos regimes totalitários. Sua obra evolui, em parte, visando a se distanciar dos malefícios que a vida inserta em tais ideologias traz à humanidade, ao fim de sua vida voltando a uma filosofia libertadora do indivíduo, das suas ações e de seu pensamento, não à toa muitas vezes figurando como bandeirante da dignidade da pessoa humana nos tempos atuais.

\subsection{Por que partir do} pensamento arendtiano?

A primeira grande obra publicada por Hannah Arendt, As origens do Totalitarismo, ${ }^{12}$ já no seu 'exílio' em terras americanas, enfoca precisamente questões que envolveriam políticas 'totalitárias' (e a autora classifica como tais, tanto a ideologia nazista, quanto o regime comunista, colocando lado-alado Hitler e Stalin).

Um dos ônus que este texto se propõe é demonstrar que alguns caracteres que Arendt identificou como envolvidos no terror totalitário (ou dele causadores) são exatamente alguns dos que norteiam nossa disciplina processual - tanto na teoria quanto na prática. As constatações que a filósofa fez a partir de sua experiência no julgamento de Eichmann, em Jerusalém, ${ }^{13}$ nos levam a refletir que os piores males são os cometidos quando não temos consciência deles, e não quando se busca efetivamente o mal. Tenciona-se mostrar o quanto nossos procedimentos judiciais tecnicistas afastam os juristas, pelo bem do Estado tecnocrata e burocrata, da realidade e da consciência, do social e do coletivo.

O segundo objetivo é o de buscar algumas idéias que levem a um Processo mais democrático, mais humano e menos ideológico (em termos arendtianos). Arendt, após identificar os problemas que levaram ao esvaziamento do ser humano e que, por isso, permitiram as atrocidades que foram cometidas na Alemanha nazista (e que ainda são praticadas - embora em muito menor grau - todos os dias em todo regime burocratizado), procura insistentemente por soluções.

Essas alternativas passam pela busca da 'realidade' perdida, afastada do conhecimento do homem, trocada por uma ideologia vazia, a qual pregava uma ausência de pensamento e de reflexão. Parte da solução do problema

12 No original, The origins of totalitarism (1951).

13 Elaboradas na obra Eichmann em Jerusalém: um relato sobre a banalidade do mal. Tradução: José Rubens Siqueira. São Paulo: Companhia das Letras, 1999. 
passa justamente por um 'parar para pensar', ${ }^{14}$ por uma reconstrução da própria realidade do mundo a partir do senso comum aos indivíduos, da reconstrução da realidade de um mundo compartilhado, e não mais de uma existência individualista e solipsista que rompe com a medida da existência.

No objetivo mediato deste degrau da pesquisa está justamente a utopia de tencionar um processo que reconecte a sociedade a si mesma; em outras palavras, que leve os administradores da justiça a se voltarem para o mundo coletivamente construído, negando a idealização de seu mundo particular em detrimento da realidade. A alteridade, $o$ outro, é que permite que o meu próprio mundo seja construído e faça sentido. ${ }^{15}$ Como já foi dito na tradição arendtiana, o ato de julgar é possivelmente o mais delicado, precisamente por ser o ato de compartilhar o mundo com esse outro. ${ }^{16}$

Em suma, é justamente na negação, na superação e na descoberta dos malefícios desse pensamento moderno voltado à burocracia e aos fins de um Estado-eficiência que o pensamento arendtiano nos é primoroso. Já é hora de darmos um passo adiante do formalismo vazio, tão criticado e tão praticado; não para negar o que ele nos pode trazer de bom (o que não é objetivo deste texto, pelo contrário), mas para aprender também o que ele nos pode trazer de ruim, de maléfico. É preciso buscar algo que seja sincrônico com a humanidade no seu estágio de desenvolvimento atual, claramente não mais a mesma dos séculos XVII e XVIII, dos quais o modelo cientificista não mais nos deveria servir - menos ainda sem uma profunda reflexão.

\subsection{A verdade e opinião}

Primeiramente, é de se salientar que o pensamento de Hannah Arendt não é sistemático ou linear; pelo contrário, suas idéias evoluíram e transmudaram ao longo de sua vida. Dessa forma, muitos conceitos e noções criados pela autora são trazidos de forma diferente, e às vezes até contraditória, em uma ou outra de suas obras.

Em particular, sobre o conceito de verdade buscaram-se bases principalmente no ensaio Verdade e Política, publicado em português como um volume independente ${ }^{17}$ - além de outras

14 A expressão é corrente no pensamento arendtiano. Ver ARENDT, Hannah. A Vida do Espirito: o pensar, o querer, o julgar. Tradução: Antônio Abranches e Helena Martins. Rio de Janeiro: Relume Dumará, 2000, passim; também SOUKI, Nádia. Hannah Arendt e a Banalidade do Mal. Belo Horizonte: Editora UFMG, 1998, p.129.

15 ROVIELlO Anne-Marie. Senso Comum e Modernidade em Hannah Arendt. Trad. Bénédicte Houart e João Felipe Marques. Lisboa: Instituto Piaget, 1987, p.121.

16 Ibidem, p. 112; Cf. ARENDT, A Vida do Espírito, passim.

17 ARENDT, Hannah. Verdade e Política. Trad. Manuel Alberto. Lisboa: Relógio d’Água Editores, 1995. 
versões insertas em volumes maiores (e.g. in Entre o passado e o Futuro, São Paulo, Editora Perspectiva, 1968; ou in A dignidade da política. Organizador: Antônio Abranches. Rio de Janeiro: Relume-Dumará, 1993, p.91115). Nele, a autora parte da condição de os homens viverem em conjunto, em um mundo que partilham e para o qual constroem livremente o significado.

Arendt identifica duas instâncias em que a verdade se manifesta, às quais ela chama 'verdades filosóficas' e 'verdades de fato'. As primeiras dizem respeito ao homem na sua singularidade; são convicções íntimas, pessoais. Já as segundas são os acontecimentos do mundo, 'acontecimentos originais'; são o passado, ocorrências sobre as quais não temos controle, não temos como modificar. Nesse sentido, a autora define: "[c]onceitualmente, podemos chamar verdade àquilo que não podemos mudar."18

Mas é no contexto de homem político, de coletividade, de homem 'condenado' a repartir o mundo com o 'outro', que Hannah noticia o que vai chamar de impotência da verdade. Isso porque a verdade só é válida no contexto singular; na passagem para o plural, essa verdade racional se transmuda em opinião. ${ }^{19}$
Quanto à verdade filosófica, a autora afirma que, "quando surge na praça, muda de natureza e torna-se opinião, porque se produz [...] um deslocamento não apenas de uma espécie de raciocínio para outro, mas de um modo de existência humana para outro." ${ }^{20}$ Já no que se refere às verdades de fato, pergunta-se se existirá algum fato para além da opinião e da interpretação. Arendt vai afirmar que inexiste a possibilidade de constatar fatos sem os interpretar, no seguinte sentido:

Não demonstraram gerações de historiadores e filósofos da história a impossibilidade de constatar fatos sem os interpretar, na medida em que têm de começar por ser extraídos de um caos de puros acontecimentos (e os princípios da escolha não são certamente dados de fato), serem em seguida organizados numa história que não pode ser contada a não ser numa certa perspectiva, que nada tem a ver com o que aconteceu originalmente? ${ }^{21}$

É interessante ver a análise que a autora faz das tentativas de levaremse as verdades à coletividade. Lembremos que o termo 'política' aqui não está sendo empregado apenas no sentido de 'política partidária', mas, sim, como um espaço destinado ao humano na sua pluralidade, na natureza social do

18 Ibidem, p.59.

19 Ibidem, p.20; também em ROVIELLO, Op. Cit., p.112.

20 ARENDT, Verdade e Política, p.24.

21 Ibidem, p.25. 
homem, no sentido aristotélico de 'homem político'. ${ }^{22}$ Nesse contexto, o que é político é o que diz respeito ao homem na coletividade, em oposição à sua singularidade.

Arendt afirma que, se o filósofo quiser ver prevalecer a sua verdade sobre as opiniões da multidão, sofrerá uma derrota. Disso, conclui que "a verdade é impotente", e que tal asserção é "um truísmo tão pleno de sentido como o do matemático, que, incapaz de realizar a quadratura do círculo, lamentasse o fato de o círculo não ser quadrado." ${ }^{23}$ Mas isso não é tudo: se quisesse fazê-lo mediante imposição, instituiria uma tirania da verdade - e a autora faz referência às diferentes utopias políticas que conhecemos, "tão tirânicas como quaisquer outras formas de despotismo." Por fim, mesmo que obtivesse sucesso sem o uso da força, teria conseguido uma vitória de Pirro. Isso porque a verdade venceu, não pela sua própria essência constrangedora, mas porque os homens se puseram de acordo para isso: "o que tinha sido verdade filosófica ter-se-ia tornado simples opinião." 24

As verdades de fato não escapam à mesma constatação. Arendt afirma que, se aquele que afirma algo quiser desempenhar um papel político (ou seja, quiser fazer valer sua opinião na coletividade), quase sempre "procederá consideráveis desvios para explicar por que é que a sua verdade serve melhor aos interesses de qualquer grupo. ${ }^{25}$ Essa constatação não é uma condenação ao mau-caratismo: pelo contrário, coaduna-se com a afirmação feita acima, de que não há constatação de fatos independentemente de interpretação. Se o indivíduo possui certa finalidade ao interpretar fatos (mesmo que seja apenas a compreensão), certamente essa interpretação e a descrição jamais corresponderão ao fato-em-si.

No entanto, essa ausência de maucaratismo na tranformação de fato em compreensão-do-fato leva à perda da boa-fé pessoal, caso aquele que diga a verdade de fato se identifique com qualquer interesse particular ou grupo de poder. A garantia dessa boa-fé, segundo a autora, é a imparcialidade, a integridade e a independência. ${ }^{26}$ É de se notar que Arendt se contradiz um pouco nessa questão, mas não ao ponto de invalidar o que afirma. Basta atentarmos para o fato de que esse 'qualquer interesse particular' é um interesse particular do próprio sujeito que se expressa, uma finalidade que tem em sua ação de comunicar o que tem por verdade de fato.

22 ARISTÓTELES. Política, §10. São Paulo: Martin Claret, 2005, p.49.

23 ARENDT, Verdade e Política, p.35.

24 Idem, ibidem.

25 Ibidem, p.41.

26 ARENDT, Verdade e Política, cit., p.41. 
A relação desse estatuto da verdade com o processo judicial será tratada mais adiante no texto. Contudo, para já marcar um dos pontos relevantes: o juiz sempre possui (e deve possuir) um interesse na descrição dos fatos - o de fundamentar e justificar sua decisão. Se não há interpretação independente do sujeito, há ainda mais uma razão relevante para se afastar a já combatida neutralidade do magistrado. Essa parcialidade - sim, porque qualquer visão é sempre parcial - não significa má-fé ou mau julgamento, mas humanidade do julgador. ${ }^{27}$

É interessante essa complementação, e não exclusão, que opera entre a verdade e a opinião: enquanto aquela diz respeito ao indivíduo, na sua singularidade (como já exposto), esta só toma consistência na medida em que se depara com outras opiniões. A partir dessa idéia é que a noção de realidade, e de uma realidade construída e constituída pela pluralidade de indivíduos - um senso comum -, começa a desenhar sua importância: essa construção da opinião somente se opera no momento em que ela é vista em perspectiva, a partir de outra opinião sobre o mesmo mundo, compartilhado. ${ }^{28}$

A supressão do status de opinião que define toda a comunicação é uma das formas que toma a tirania, a ideologia. Essa noção será tratada mais adiante, mas cumpre já frisar as conseqüências às quais relação entre verdade e opinião podem apontar:

\begin{abstract}
Os modos de pensamento e de comunicação que têm a ver com a verdade são, quando considerados na perspectiva política, necessariamente tirânicos; não têm em conta opiniões de outros, quando esse ter em conta é a marca de todo o pensamento estritamente político. ${ }^{29}$
\end{abstract}

\subsection{Política, senso comum, realidade e sentido}

A questão política por excelência é a questão do mundo enquanto mundo comum, ou seja, é o que diz respeito ao mundo que, enquanto seres humanos coletivos, compartilhamos. "O campo da política é o do pensamento plural, é o pensar no lugar e na posição do outro." ${ }^{30}$ O espaço público, por sua vez é onde se institui e onde acontece essa perspectivação das opiniões, a qual cria, dá substância, ao mundo comum. Esse espaço se pode encontrar em qualquer esfera da atividade humana, e não apenas nas instituições públicas oficiais. ${ }^{31}$

O 'senso comum' não é uma verdade positiva comum presente em

27 Cf. CARDOZO, Benjamin N. A Natureza do Processo Judicial. São Paulo: Martins Fontes, 2004, p.3 et passim.

28 Cf. ROVIELLO, Op. Cit., p.112.

29 ARENDT, Verdade e Política, cit., p.28.

30 SOUKI, Nádia. Op. Cit., p.44.

31 ROVIELLO, Op. Cit., p.187. 
cada indivíduo, ${ }^{32}$ não é uma decisão ou uma adesão da maioria; muito menos é um consenso ou uma unanimidade. Pelo contrário, o pensamento arendtiano oferece a unanimidade como um sintoma de desaparecimento do senso público. Hannah Arendt é enfática nesse sentido: "[o] mundo comum acaba quando é visto somente sob um aspecto e só se lhe permite uma perspectiva." ${ } 33$

Bethânia Assy faz uma bela descrição do que seria o senso comum, mostrando-o a partir da relação que tem com o julgamento, com o ato de julgar:

(...) o sensus comunis é concebido tal qual um senso que nos ajustaria à pluralidade, e não a um consenso coletivo ou a uma decisão política unânime. Arendt afirma no manuscrito de 1965 'levar o outro em consideração quando eu julgo não significa uma conformidade entre meu julgamento e o dos outros. Eu ainda me refiro à minha própria opinião e não levo em conta a quantidade de outros quando chego à conclusão de que algo está certo. Todavia, meu julgamento deixa de ser simplesmente subjetivo, no sentido de que não considero apenas a mim mesma quando julgo'. [...] Não iniciamos ab ovo nem criamos ex nihilo. ${ }^{34}$

Nesse sentido, o que garante um ato de julgar não arbitrário e não solipsista é precisamente esse contato com o senso comum. Nas palavras de AnneMarie, "É precisamente esta referência do senso comum que permite estabelecer a diferença entre a opinião verdadeira e a arbitrariedade subjetiva." ${ }^{35}$ Isso porque, se o próprio mundo é constituído pelo debate, pela perspectivação de opiniões, uma opinião que não se refere ao senso comum não é construída a partir do mundo compartilhado com os outros homens. Julgar tomando por base apenas o seu mundo, as suas opiniões (ou, quem sabe, as suas verdades), é praticar uma arbitrariedade subjetiva. ${ }^{36}$

Mais que uma descrição do mundo, o senso comum é a própria condição de sentido de um mundo compartilhado. Seu desaparecimento é a prova de que não se compreende coletivamente esse mundo, enquanto o próprio senso de realidade de um mundo que é comum a

32 Cfe. ROVIELLO, Op. Cit., p.116.

33 ARENDT, Hannah. A Condição Humana. Trad. Roberto Raposo. Rio de Janeiro: Forense Universitária, 2005, p.68.

34 ASSY, Bethânia. Introdução à edição brasileira de Responsabilidade e Julgamento, in ARENDT, Hannah. Responsabilidade e Julgamento. Trad. Rosaura Eichenberg. São Paulo: Companhia das Letras, 2004, p.49.

35 ROVIELLO, Op. Cit., p.112.

$36 \mathrm{O}$ outro extremo do que seria, poderíamos dizer pela argumentação, uma arbitrariedade objetiva, que é o julgamento sem reflexão, heterônomo. Esse outro tipo de ação é típico das ideologias, sobretudo totalitárias, e será amplamente tratado abaixo. 
mais de uma pessoa nasce do debate que se faz sobre ele. ${ }^{37}$

É importante salientar que não é apenas um debate sobre o mundo, mas que esse debate é a própria instituição de um mundo comum - o qual só existe na medida em que os indivíduos sobre ele discutam. ${ }^{38}$ É nesse sentido que o 'político' é tão importante para Arendt. O espaço público, o debate, é central para o ser humano justamente porque é "o espaço por excelência onde se pode realizar, ao instituir-se livremente, a condição do homem enquanto ser-deste-mundo. $\mathrm{Na}$ e pela instituição da sociedade humana estabelecem-se os laços entre o homem, o mundo e o sentido." ${ }^{\prime 39}$

Há no pensamento arendtiano uma passagem de uma especulação metafísica para um 'juízo político', para um mundo construído a partir da comunidade de sentido. Nas palavras de Roviello, "a comunidade de sentido fundada na 'intersubjetividade do mundo' toma o lugar da verdade eterna e imutável." O sentido revela-se apenas na partilha, do mundo e do próprio sentido; essa partilha, essa comunhão impede que as perspectivas se fechem em si próprias, constituindo mundos privados. ${ }^{40}$

$\mathrm{O}$ 'problema' vem à tona justamente quando se quer impor esses mundos privados ao outro. No momento em que não há uma abertura à alteridade, ao sentido constituído na comunidade, há arbitrariedade, há necessariamente a tentativa de impor verdades (vez que de opinião não se trata, por carecer de perspectiva), conforme descrito no subcapítulo acima.

A exigência da razão, nesse contexto, não é, segundo Hannah Arendt, dar conta de tudo o que existe e acontece. ${ }^{41}$ Não é a sede de saber que determina a razão, mas a busca de sentido. Essas questões constituem em sua essência uma verdadeira abertura para o mundo, uma insersão nesse mundo através da compreensão. ${ }^{42} \mathrm{~A}$ abertura para o mundo é que significa abertura para o outro; essa abertura ao mundo não quer dizer procurar o compreender sozinho, isolado em um mundo individual e próprio, mas uma abertura à opinião do outro quanto ao mundo que compartilham.

\subsection{Ideologia, totalitarismo,} banalidade do mal e mal radical

A ideologia, no pensamento arendtiano, significa o pensamento que já não é exercido nesse contato com o mundo comum, com essa realidade constituída e instituída, mas que é

37 ROVIELLO, Op. Cit., p.116.

38 Ibidem, p. 174

39 Ibidem, p.8.

40 Ibidem, p.111-112.

41 ARENDT, A Vida do Espírito, passim.

42 Cf. ROVIELLO, Op. Cit., p.108. 
realizado à parte dela. ${ }^{43} \mathrm{O}$ pensamento ideológico é caracterizado por erguer uma parede entre o indivíduo e a realidade; a experiência particular é substituída por um "sobre-sentido prefabricado da ideologia." 44

O discurso ideológico é precisamente o que se propõe a transmitir, não opiniões, mas verdades. A ideologia totalitária, indo além, não é, nas palavras de Anne-Marie, "um pensamento que se equivoca ou um pensamento falacioso; é um pensamento que se nega a si próprio, um pensamento que tem como objetivo não pensar." ${ }^{45}$

A primeira negação que o sujeito realiza (conscientemente ou não) ao se apropriar de um discurso ideológico é o da sua autonomia. E essa foi uma das características marcantes que Arendt idendificou em Eichmann, quando assistiu a seu julgamento em Jerusalém. Ele não era um monstro, como ela (e muitos à época) imaginavam. Ao contrário, a filósofa viu no alemão uma pessoa vazia - ao que se referiu como alguém que não pensava. Além disso, era um homem com extremo grau de heteronomia. ${ }^{46}$ Há um trecho escrito por Nádia Souki, esclarecedor nesse sentido:
Se todo pensar exige um 'pare-e-pense', tal movimento permanente é incompativel com a atividade de pensar. Nessa pausa onde o homem pode suspender, provisoriamente, seus juizos de valor e suas certezas prévias, 'parar-parapensar' é o primeiro ato de resistência a uma imposição externa, a uma exigência de obediência. É exatamente nessa parada, momentânea mas decisiva, que o homem pode começar a realizar sua autonomia. E esse fluxo contínuo, que interdita qualquer parada, qualquer pensamento, tem como objetivo, exatamente, o automatismo em que os homens deixam de interrogar para, prontamente, obedecer. ${ }^{47}$

Essa é a ligação da burocracia com o regime totalitário. O Estado-eficiência insere o indivíduo em uma máquina burocrática que lhe impede qualquer julgamento por si, qualquer tomada de decisão independente, qualquer autonomia. O 'modelo' de cidadão das sociedades burocratas é aquele que atua sob ordens, que é incapaz de pensar por si mesmo. A espontaneidade do pensamento é abolida. ${ }^{48}$

A própria linguagem ideológica desempenha um papel fundamental nesse fechamento à reflexão (e ao contato com a realidade). Souki afirma

43 Cf. ROVIELLO, Op. Cit., p.106.

44 Ibidem, p. 129.

45 Ibidem, p.131.

46 SOUKI, Op. Cit., p.37.

47 Ibidem, p. 129.

48 Cf. SOUKI, Op. Cit., p.13. 
que "[o]s clichês, as frases prontas, os códigos de expressão padronizados e convencionais servem para proteger os indivíduos da realidade levando-os a viver e agir em um mundo totalmente irreal." "49 A autora denomina essa linguagem como 'linguagem burocrática', cuja função fundamental seria "criar uma apaziguadora ilusão para os executantes e para os executados [nos campos de concentração], pois estes últimos nem de longe entendem o significado dessas palavras. ${ }^{\circ 0}$

Arendt avalia que a 'maldade' e a 'perversidade' de Eichmann está ligada a uma incapacidade para julgar, a uma verdadeira recusa de pensar. O alemão não conseguia, segundo ela, se colocar a questão do sentido e, principalmente, a questão do sentido das suas ações. Lembrando que o sentido é constituído pela comunidade, Eichmann não possuía a capacidade de ver seus atos pela perscpectiva exterior à sua ou à da ideologia que lhe foi imposta. ${ }^{51}$

$\mathrm{O}$ que Arendt denomina de 'banalidade do mal' está ligado a esse vazio de pensamento, ou a essa ausência de pensamento. $\mathrm{O}$ mal extremo não se encontra em uma subjetividade per- versa, mas na anestesia da subjetividade, em uma não-reflexão. Como diz Roviello, "enquanto somos incapazes de pensar sobre o mal somos tanto mais capazes de o praticar. É na própria medida em que omitimos pensar sobre o mal no qual tomamos parte, que podemos realizá-lo melhor. ${ }^{52}$

Aí é onde está a maior perversidade: o mal que não é perverso, que não tem motivos especiais é justamente o que pode ser um mal infinito,$^{53}$ pois sequer é pensado, sequer é refletido. "O mal humano é ilimitado quando não gera nenhum remorso, quando os atos são esquecidos assim que são cometidos." ${ }^{\text {54 }}$

Já o 'mal radical' arendtiano (cronologicamente abordado antes da criação da expressão 'banalidade do mal') tem clara inspiração kantiana. Arendt vai referir, em mais de uma ocasião: “eu não sei o que é o mal radical, mas eu sei que ele tem a ver com esse fenômeno: a superfluidade dos homens enquanto homens." ${ }^{55}$ Esse mal se realiza, tanto para Kant quanto para Arendt, quando o homem deixa de ser um fim em si mesmo, quando ele se torna um meio, um instrumento. A sua

49 SOUKI, Op. Cit., p.107.

50 Ibidem, p.95.

51 ROVIELLO, Op. Cit., p.110.

52 Ibidem, p. 159.

53 Cf. SOUKI, Op. Cit., p.71.

$54 \mathrm{KOHN}$, Jerome. Introdução à edição americana de Responsabilidade e Julgamento, in ARENDT, Responsabilidade e Julgamento, p.19.

55 Citado, dentre outras obras, em SOUKI, Op. Cit., p.105. 
própria existência passa a ser condicionada a um valor utilitário. ${ }^{56}$

O próprio ser humano se torna descartável. O homem é apenas mais um dente da engrenagem, alguém cuja substituição nada muda no 'sistema' essa é uma das pressuposições de todas as burocracias, de todo serviço público burocratizado ao extremo. É interessante que Hitler, durante o terceiro Reich, se definiu como "o único homem insubstituível em toda a Alemanha.", asserção considerada correta por Arendt. ${ }^{57} \mathrm{~A}$ autora se refere à burocracia como "infelizmente o mando de ninguém e, por essa mesma razão, talvez a forma menos humana e mais cruel de governo. ${ }^{58}$

\section{5 Ética e responsabilidade}

Na ética arendtiana, a dualidade ato/ intenção desaparece. O quem somos não vai se dar pelo nosso encerramento em intenções, mas pelo que transmitimos na visibilidade do espaço público. Como afirma Bethânia Assy, "a ética da responsabilidade não se compromete com as chamadas 'melhores intenções', que repousam invisíveis na escuridão privada de nosso coração." 59
A própria personalidade do indivíduo é 'construída' da mesma forma que qualquer outra realidade do mundo: por meio da perspectivação de opiniões. É aí que importa o visível, e quem somos não depende de quem queremos ser, mas da imagem que passamos tanto por nossos julgamentos quanto por um "agir consistente. ${ }^{960}$ Nas palavras de Hannah Arendt, "[n]este mundo em que chegamos e aparecemos vindos de lugar nenhum, e do qual desaparecemos em lugar nenhum, Ser e Aparecer coincidem."'61

Essa leitura da ética muda completamente o enfoque ordinário. Não estamos mais fechados em nós mesmos, avaliando nossas ações a partir da nossa perspectiva, sendo o nosso próprio juíz. Arendt afirma que ninguém pode ser o juiz do seu próprio caso (ou, no contexto em que apresenta, o juiz de si mesmo), pois sempre acreditou não ser possível alguém "conhecer a si mesmo, porque ninguém aparece para si mesmo assim como aparece para os outros. Só o pobre Narciso vai se deixar enganar pela sua própria imagem refletida, definhando por amor a uma miragem."

Isso porque o sentido da ação só se configura a partir do senso comum

56 SOUKI, Op. Cit., p.105.

57 ARENDT, Responsabilidade e Julgamento, p.91-92.

58 Ibidem, p.94.

59 ASSY, Bethânia in ARENDT, Responsabilidade e Julgamento, p.53.

60 ASSY, Bethânia in ARENDT, Responsabilidade e Julgamento, p.56.

61 ARENDT, Op. Cit., p.17.

62 Idem, Responsabilidade e Julgamento, p.69. 
- como já explicado acima. O julgamento da nossa conduta é feito pelo outro ou, mais propriamente, pelos outros, em uma constituição de sentido que trespassa o individual, o particular. Essa presença do outro (que muitos, na sua submersão em um pensamento individualista, classificam como 'incômoda') não é apenas uma espécie de condenação que sofremos por viver em comunidade; é, ao mesmo tempo, nossa salvação: ela é a única garantia da nossa existência enquanto humanos, é a condição de nosso próprio sentido.

O pensamento arendtiano nesse ponto tensiona um paradoxo. Se um dos 'problemas' identificados por Arendt na personalidade de Eichmann era sua falta de capacidade para julgar os próprios atos atribuindo-lhes sentido, como poderia ele nesse caso ser juiz de seus próprios atos?

A questão apresenta-se delicada, mas buscar elucidá-la é de grande valia. Eichmann foi, de certa forma, o juiz de seus próprios atos. Quando interrogado pela polícia israelense, afirmou que tinha 'conduzido toda a sua vida de acordo com os preceitos morais de Kant' ${ }^{63}$ Ao que parece, essa pretensa 'retidão moral' de nada adiantou, haja vista as atrocidades que cometeu.

A carência do alemão foi a atribuição de sentido. Certamente para ele os atos que cometera tinham um significado, enquanto para (quase todo) o resto da humanidade, outro. Esse distanciamento, que Arendt afirma ser um distanciamento da própria realidade, ${ }^{64}$ é que lhe permitiu manter sua conduta - inclusive acreditando que era de uma correção moral impecável.

O exemplo, que foi chocante para Arendt e acabou por lhe redirecionar todo o seu pensamento, é claro para demonstrar que a mera reflexão solipsista não é suficiente para a busca de qualquer ética. A reflexão proposta - e é aí que o indivíduo não pode se julgar por si mesmo - é a abertura ao sentido da ação, que quem lhe dá é a comunidade de sentido, pelo exercício da abertura ao outro, à alteridade. Essa abertura tampouco significa heteronomia; pelo contrário, é condição de autonomia em contato com o mundo. O senso comum não é a vontade de outrem, mas o senso de realidade que norteia a atribuição de sentido ao real.

A ideologia vem ao encontro do desejo dos indivíduos de se descartarem da sua responsabilidade, de se limitarem a "seguir o movimento." 65 Vem confortar aqueles indivíduos que, como mencionou Foucault, possuem um desejo de não ter que 'começar' ${ }^{66}$ Não pensar naquilo que fazemos, para nós,

$63 \mathrm{KOHN}$, Jerome, in ARENDT, Responsabilidade e Julgamento, p.16.

64 Cf. Supra.

65 ROVIELLO, Op. Cit., p.132.

66 FOUCAULT, Michel. A Ordem do Discurso. Tradução: Laura Fraga de Almeida Sampaio. São Paulo: Loyola, 2005, p.6 et passim. 
parece significar não termos que responder por aquilo que fazemos. ${ }^{67}$

Arendt critica aqueles que 'não querem pensar'. Segundo ela, são muito mais confiáveis os céticos, "não porque o ceticismo seja bom ou o duvidar, saudável, mas porque são usados para examinar as coisas e para tomar decisões. ${ }^{~} 68$ É o refletir no que se está fazendo, buscando como ponto de partida e chegada do pensamento o senso comum, o real, o mundo compartilhado, que se busca evitar o afastamento do mundo - causa de uma ditadura de uma verdade imposta (ou pressuposta).

A autora faz uma clara separação entre 'culpa' e 'responsabilidade'. A primeira seria estritamente pessoal, e diz respeito a questões morais ou legais. A afirmação de que "somos todos culpados" $" 69$ por algo serviria de fato apenas para desculpar aqueles que são realmente culpados. Arendt afirma categoricamente: "[q]uando somos todos culpados, ninguém o é." $" 70$

Por outro lado, a responsabilidade é coletiva e, nesse sentido, política. Segundo a autora, toda a comunidade a assume "por qualquer ato de qualquer de seus membros'. ${ }^{71}$ Afirma ela: "[t]odo governo assume a responsabilidade pelos atos e malfeitorias de seus predecessores, e toda a nação pelos atos e malfeitorias do passado", ${ }^{72}$ e só se pode escapar dessa responsabilidade abandonando a comunidade - ainda que nenhum ser humano possa viver (enquanto humano) sem pertencer a alguma comunidade.

A responsabilidade pelo que não fizemos 'é o preço que pagamos por levar nossa vida não conosco mesmos, mas entre nossos semelhantes'. Para Hannah Arendt, "nenhum padrão moral, individual e pessoal de conduta será capaz de nos escusar da responsabilidade coletiva." ${ }^{\text {73 }}$ A questão passa a ser, não como evitá-la, mas como assumi-la.

É no 'parar-para-pensar' que o homem resiste a uma imposição externa, à obediência cega. É nessa parada que o homem pode realizar sua autonomia - e o fluxo contínuo da burocracia tem como objetivo exatamente o automatismo, o homem que deixe de interrogar para prontamente obedecer. De acordo com Souki, é relevante Arendt ter

67 ROVIELLO, Op. Cit, p.160.

68 ARENDT, Responsabilidade e Julgamento, p.108.

69 Como no caso dos alemães a respeito do regime nazista, ou dos brancos liberais a respeito dos negros, como citado pela própria autora em $\mathrm{H}$. Arendt, Responsabilidade e Julgamento, p.213, 214.

70 ARENDT, Responsabilidade e Julgamento, p.214.

71 Ibidem, p.216.

72 Ibidem, p. 217.

73 Ibidem, p.225. 
baseado sua teoria na autoridade de Santo Agostinho, pois para este o homem é livre porque é o começo. "Para Agostinho, Deus criou o homem para introduzir no mundo a faculdade de começar: a liberdade." ${ }^{\prime 7}$

\section{VISÃO CRÍTICA DO PROCESSO E DA JURISDIÇÃO}

Neste capítulo, serão abordados alguns aspectos críticos do processo judicial e da jurisdição, principalmente sob o enfoque dos juristas e processualistas já apontados, ${ }^{75}$ visando a apontar algumas possíveis relações entre suas idéias e o pensamento arendtiano.

\subsection{Verdade ou sentido?}

Ovídio Baptista salienta, no decorrer de suas obras, o quanto ainda estamos arraigados em um pensamento atrelado ao paradigma racionalista, ou seja, à busca de "verdades absolutas" ${ }^{96}$ pelo indivíduo. Este pensamento, tornado alicerce do liberalismo, para que atinja seus objetivos, deve valer-se apenas da razão, "desligado de seus laços culturais e livre da tradição e das doutrinas filosóficas tradicionais."

Se assumirmos o pensamento arendtiano nesse ponto, ou, ao menos, o considerarmos válido, a 'verdade' se atingida - será ideológica ou solipsista. A busca da verdade não é absurda nem impossível, mas ideológica. Ovídio Baptista bem se reporta ao assunto como 'componente autoritário', traçando um paralelo com Hobbes e a sua concepção de Estado absoluto. Refere, ainda, que "Estados modernos levaram ao extremo [...] um Direito produzido pela vontade do soberano para ser 'consumido' pela nação."”78

Esse tipo de concepção de construção do Direito só autoriza três caminhos: impor uma ideologia, impor uma arbitrariedade ou falhar. Salvo a terceira hipótese, será necessariamente anti-democrática (como o seria qualquer 'ditadura da verdade" $\left.{ }^{79}\right)$. Foi assim que a Alemanha nazista procurou levar a cabo um dos anseios do racionalismo, o ideal de certeza: o princípio soberano era o da vontade do Führer ${ }^{80}$ - e esta

74 SOUKI, Op. Cit., p.43.

75 Cf. Supra.

76 SILVA, Ovídio A. Baptista da. Jurisdição e Execução na tradição romano-canônica.

São Paulo: Revista dos Tribunais, 1996, p.103.

77 SILVA, Ovídio A. Baptista da. Processo e Ideologia, p.6.

78 Ibidem, p.51.

79 Cf. Supra.

80 Eichmann afirmou que "não tinha obedecido simplesmente à lei da Alemanha de Hitler, mas tinha identificado a vontade do Führer 'com o princípio por trás da lei". KOHN, Jerome, in ARENDT, Responsabilidade e Julgamento, p.16. 
pode ser sempre verificada. "O Direito 'perfeito' elimina qualquer tentativa de questionamento. É o direito do tirano." $" 1$

À parte dessa busca de uma verdade, do certo e imutável, a operacionalização do jurídico pode visar ao sentido. Tomemos a lide como não sendo mais que uma "pequena unidade da história, vivida por seres reais." ${ }^{\circ 2} \mathrm{E}$, mais ainda, como uma discussão acerca de outra (pequena) unidade da história: os fatos litigiosos. Ora, o fato histórico é compreendido, jamais explicado "como se explicam as experiências no domínio das ciências modernas." ${ }^{" 83}$

Que é a lide, então, senão a busca do sentido referente aos fatos controversos ${ }^{84}$ Da discussão acerca da atribuição - ou não - de sentido jurídico aos fatos, e do sentido dessa mesma atribuição?

Nesse contexto, em um regime democrático $^{85}$ não cabe ao juiz impor o sentido de um 'superior hierárquico' ou o seu próprio. Lembremos o pensamento arendtiano, ao qual Roviello assim se refere: "julgar significa partilhar o mundo com outrem, e a modalidade desta partilha é a persuasão, não o constrangimento, ainda que fosse o da verdade." ${ }^{86}$

O papel do magistrado não é impor uma leitura de mundo (ou dos fatos), mas construí-la juntamente com as partes litigantes. O contato do julgador com o senso comum, com o sentido constituído pela comunidade, dá-se pela sua abertura à alteridade: pela sua abertura ao sentido exposto pelos seus interlocutores no processo. O sentido construído pela sociedade, e esta mesma, são ouvidos por intermédio das partes que litigam. E essa abertura é que legitimaria $o$ ato jurisdicional.

Um dos primeiros entraves que há no processo à busca de sentido do próprio processo (e, com ele, do Direito) é a ausência de debates. A discussão é resumida (ou aleijada) a uma enunciação individual e solipsista de cada parte. Cada um fala de seu lugar de fala - não há abertura ao outro. Há a

81 SILVA, Ovídio A. Baptista da. Processo e Ideologia, p.93.

82 SILVA, Ovídio A. Baptista da. Processo e Ideologia, p.266.

83 Ibidem, p.290.

84 Ovídio Baptista vai referir que “'[o] processo moderno pressupõe a existência do 'fato', em sua materialidade, e não o 'sentido' que o 'fato' possa adquirir no interior de cada lide.” In Fundamentação das Sentenças..., p.328.

85 Não faço menção à democracia apenas enquanto regime de governo, mas, de acordo com o pensamento arendtiano, enquanto constituição da própria realidade - em oposição ao totalitarismo (também no sentido atribuído pela autora), o qual não se limita às atividades de governo, mas impõe arbitrariamente toda a realidade.

86 ROVIELLO, Op. Cit., p.112. 
'apresentação' de dois pontos de vista, mas não o diálogo necessário à constituição de um senso comum. ${ }^{87}$

Mais: esse debate só seria perfectibilizado com a participação do julgador. Como bem demonstra Ovídio, ${ }^{88}$ este é um dos maiores dogmas de nosso processo judicial: o juiz não pode se manifestar antes de convencido, antes de proferir a 'verdade'. Entretanto, se tomarmos ' $a$ ' verdade por indesejável (pelos motivos já expostos), é sem sentido que o magistrado assim se comporte. Não mais se lhe é exigida a imposição de uma sabedoria atemporal, mas apenas a solução da lide. E esta deve ser construída, constituída, por meio da linguagem, da argumentação, em uma abertura ao sentido trazido pelas partes.

O julgador não profere uma 'verdade' em sua decisão (a não ser em regimes autoritários/totalitários), mas uma opinião $0^{89}$. Esta, lembrando, só tem consistência se perspectivada por outras opiniões - e a possibilidade de questionamento lhe é fundamental. A legitimidade da decisão não mais é um juízo de certeza (falacioso ou impositivo), mas um juízo responsável, ou seja, um juízo aberto à constituição de sentido pelo senso comum.
Em suma, a constituição de sentido da decisão é construída pelo magistrado por meio da abertura ao mundo, de um levar em consideração a opinião das partes, e pelo deixar as partes levarem em consideração a sua própria opinião. E é justamente esse fazer-sentido-nomundo (enquanto mundo comum, compartilhado entre o magistrado e os envolvidos) que sustenta a decisão, que a legitima-democrática ou racionalmente.

Vejamos, nesse contexto, as palavras de Ovídio Baptista:

Quando o juiz disser que julga de tal ou qual modo porque esse é o sentido da norma aplicável, ele ainda não forneceu nenhum fundamento válido da sentença. Escolhendo 'livremente' o sentido que lhe pareceu adequado, sem justificá-lo, o julgador não teria ido além do raciocínio formulado por alguém proibido de explicitar os fundamentos da decisão. [...] A exigência de que a motivação seja 'completa', abrangendo tanto a versão aceita pelo julgador, quanto as razões pelas quais ele recusara a versão oposta, éfundamental para que o convencimento judicial alcance o nível de racionalidade exigido pela lei. ${ }^{90}$

Vemos que o autor se aproxima muito de defender o ponto aqui

87 Remete-se aqui à explicação supra, de que o senso comum não é um 'meio-termo', nem um 'mínimo denominador comum' remanescente entre a confrontação de verdades positivas diversas.

88 SILVA, Ovídio A. Baptista da. Processo e Ideologia, passim.

89 Faço menção ao conceito e ao papel da opinião no pensamento arendtiano, $c f$. supra. 90 SILVA, Ovídio A. Baptista , da. Fundamentação das Sentenças ..., p.334-335. 
sustentado, ainda que com linguagem diversa. A divergência está na questão de o magistrado poder escolher livremente o 'sentido' que lhe pareceu adequado - em uma perspectiva arendtiana, a 'escolha' individualizada, por si só, carece de sentido.

O problema não está apenas na fundamentação, a qual nos apresenta apenas o (ou um) sintoma. A questão fulcral se dá durante a lide, e não ao seu final. É lá que o magistrado deve estar aberto ao 'sentido' de ambas as partes, e não apenas na justificação (lógica e cronologicamente posterior). O sentido, na justificação (vale dizer, da decisão) é alcançado por esse 'levar em conta' as versões apresentadas, e por construir, a partir delas e com elas, em conjunto, em debate, em posição e sobreposição de opiniões, a solução para o caso. A justificação apresentada será conseqüência.

Calamandrei resume de forma bela parte do argumento que está sendo exposto (ainda que, ao menos à citação, falte boa parte do enfoque filosófico que aqui foi exposto): "[j]ustiça é compreensão: isto é, tomar em conjunto e adaptar os interesses opostos: a sociedade de hoje e a esperança de amanhã; as razões de quem a defende e as de quem a acusa." ${ }^{91}$ Já Capeletti fala em "tornar a autonomia dos juízes aberta ao corpo social e, assim, às solicitações dos 'consumidores' do supremo bem que é o da Justiça." 92

Frise-se que não se fala aqui apenas com referência às verdades de fato. Não se trata de debater apenas acerca de 'versões dos fatos', mas, também, de 'versões do Direito'. O papel do jurídico é a atribuição de sentido; e o sentido só faz sentido no coletivo, no espaço público, aberto à comunidade. Como bem refere Ovídio Baptista, "[o] sentido não está no texto. [...] Não há um sentido $a$ priori, que seja anterior e independente do respectivo contexto em que ele se insere. ${ }^{\circ 93}$ Pois é a busca desse sentido e desse contexto que é o sentido do processo judicial, quando inserido em uma comunidade democrática.

\subsection{Ideologia, burocracia e maldade}

Como desenvolvido até aqui, a ideologia choca-se diretamente com um processo civil legítimo em uma sociedade democrática. Cabe nesse contexto uma colocação de Castoriadis:

E se fosse possivel um conheci-mento seguro e completo (epistémè) do domínio humano, a política acabaria imediatamente, e a democracia tornar-se-ia, ao mesmo tempo, impossivel e absurda, pois

91 CALAMANDREI, Piero. Elogio dei giudici da un avvocato. Firenze: Le Mennier, 1955, p.269 e ss. apud CAPELETTI, Mauro. Juízes Irresponsáveis? Tradução e Revisão: Carlos Alberto Alvaro de Oliveira. Porto Alegre: Fabris, 1989, p.93.

92 CAPELLETI, Op. Cit., p.93.

93 SILVA, Ovídio A. Baptista da. Fundamentação das Sentenças..., p.331. 
a democracia pressupõe que todos os cidadãos têm a possibi-lidade de atingir uma doxa correcta e que ninguém possui uma epistémè das coisas políticas. ${ }^{94}$

Mas exatamente o que o pensamento ideológico propõe é um saber secularizado, à parte do contexto e situação históricos. "O esquecimento do passado é condição do dogma. ${ }^{95}$ Entretanto, a compreensão do passado é condição de sentido para o entendimento do presente; o esquecimento da história é a perda de sentido da existência. Nas palavras de Roviello, "procurar o sentido do passado é, assim, procurar uma primeira garantia para o sentido do presente". ${ }^{96}$

A apropriação ideológica do passado, transformado em dogma com pretensão de verdade, o anacronismo evidente das verdades secularizadas nos condena a conviver com o não-sentido. O próprio hábito (entendido no contexto de vida pós-moderna, próximo a um condicionamento, e não no sentido dos pensadores clássicos) é uma remoção da noção do tempo em nossos atos. E não é à toa que, via de regra, pessoas habituadas ou condicionadas a certas atitudes não saibam dizer o sentido desses mesmos atos e atitudes, tendo em vista que esqueceram ou sequer se puseram a pensar sobre isso. Nas palavras de Bethânea Assy:

[A]pesar da estabilidade positiva proporcionada pelos hábitos, tem-se, primeiro, a sobrevalorização da mecanização tanto das atividades mentais quanto do sentido material da realidade; e, em segundo, conseqüentemente, a promoção do que se poderia chamar de 'a seguridade de um ontem permamente'. Na mesma proporção que os hábitos contribuem para a estabilidade do mundo, asseguram uma equivocada segurança da realidade. Colocado de forma bela por Arendt já em 1928, 'o hábito é um ontem eterno e sem futuro. Seu amanhã é idêntico a hoje. ${ }^{97}$

O pensamento burocrático desempenha um papel central nesse raciocínio de fazer perdurar idéias anacrônicas. Como já apresentado acima, Hannah Arendt é enfática ao demonstrar a burocracia como um sistema que impede de pensar e que limita o acesso do homem à realidade (sincrônica). Ela corresponde a uma mecanização e a um esvaziamento do ser humano, que perde o contato com a realidade e com o senso comum. Seus atos deixam de fazer sentido, deixam de ter sentido e, por último, sua própria existência passa a ser vazia. ${ }^{98}$

94 CASTORIADIS, Cornelius. Domaines de l'homme. Les carrefours du labyrinthe II, Paris: Seuil, 1977, p.285 apud ROVIELLO, Op. Cit., p.184.

95 SILVA, Ovídio A. Baptista da. Processo e Ideologia, p.19.

96 ROVIELLO, Op. Cit., p.84.

97 ASSY, Bethânia in ARENDT, Responsabilidade e Julgamento, p.41.

98 Cf. supra. 
A busca da certeza do direito, enquanto pensamento ideológico, tem sua origem - como já referido - no racionalismo europeu, e possui uma relação estreita com o sistema burocrático de organização judiciária, o que contribui com a "assimilação da função judicial à carreira de um funcionário público comum [...]." 99 A ideologia, bem no sentido arendtiano, se manifesta na separação Direito/mundo real, como bem observa Ovídio Baptista: “[a] suposição de que a ciência do direito pudesse criar, através da razão, como pretendera Leibniz, 'verdades eternas' é a responsável pelo extraordinário divórcio entre o Processo Civil e a vida que se observa na experiência contemporânea." 100

A burocratização do Direito acaba por desempenhar essa função de abstração do jurídico em relação à realidade. A solução judicial, não raro, embora possua fundamentação dogmática, simplesmente não faz sentido no mundo - e muito menos sentido ainda no mundo não-jurídico! Como bem afirma Ovídio Baptista, "[o] 'mundo jurídico', de que tanto falava Pontes de Miranda, é o espaço criado pelas doutrinas políticas liberais para excluir o jurista do 'mundo social'."101 No mesmo parágrafo, assim expôs o jurista:
Esse exacerbado normativismo éo pilar que sustenta o dogmatismo de nossa formação universitária. É ele que permite a constituição de um ensino do Direito abstrato, formal e acrítico, permitindo que os juristas alimentem uma ilusão de produzir uma ciência do Direito neutra quanto a valores, mantendo-os distantes e alienados de seus compromissos sociais. ${ }^{102}$

O ensino jurídico dominante na atualidade (ao menos em nosso país), o qual apresenta um Direito divorciado da realidade, do sentido e do contexto social, coroa o pensamento ideológico. O aluno, em vez de aprender o 'pararpara-pensar', em vez de ser estimulado para construir, pelo estudo, pelo debate e pelo discurso, o sentido da realidade jurídica, é ensinado a buscar no jápronto (doutrina, leis, jurisprudência) a solução. O sentido não é construído, mas lhe é dado. ${ }^{103}$

Cumpre referir que essas constatações correspondem aos sintomas que Hannah Arendt identifica como originários do mal radical e da banalidade do mal. ${ }^{104}$ Quanto ao primeiro, o homem deixa de ser um fim em si mesmo: a solução da lide se vê perdida em meio à burocratização do processo,

99 SILVA, Ovídio A. Baptista da. Jurisdição e Execução ..., p.103; no mesmo sentido, ver MERRYMAN, John. La tradición jurídica ..., p.67,72 et passim.

100 SILVA, Ovídio A. Baptista da. Jurisdição e Execução ..., p.128.

101 SILVA, Ovídio A. Baptista da. Processo e Ideologia, p.50.

102 Idem, ibidem.

103 Cabe fazer referência ao ponto 2.4 , acima.

104 Cf. Supra. 
onde a justiça meramente formal e procedimental arraigada no liberalismo exacerbado toma conta.

No que se refere à banalidade do mal, em decorrência dessa burocratização, perde-se o sentido do ato praticado. Este pode ser infinitamente mal, pois nos é impedido, pelos vários artifícios do sistema - pela linguagem burocrática, pelo movimento constante de informações (em grande parte dispensáveis), pelo pensamento ideológico, pelo distanciamento Judiciáriosociedade -, que tomemos contato com o sentido da ação. O que não faz sentido não tem medida e, conseqüentemente, não tem limite.

Ensina Roviello que "[a] desmedida demonstra ser a máxima miséria, já que é acompanhada por um encerramento do sistema em si próprio; a desmedida é o solipsismo ou o narcisismo desmesurado de um fragmento do mundo que se toma pela totalidade do mundo." ${ }^{105}$ E note-se a proximidade de uma afirmação de Piero Calamandrei com a banalidade do mal pensada por Hannah Arendt:

$O$ verdadeiro perigo não vem de fora: é um lento exaurimento da consciência, que a torna aquiescente e resignada: uma crescente preguiça moral (...). Na minha longa carreira nunca me encontrei, face a face, com juizes corruptos, mas conheci não raramente juizes indolentes, desatentos, aborrecidos (...). ${ }^{106}$

Cumpre lembrar a figura de Eichmann (por ser icônica no pensamento arendtiano), ${ }^{107}$ para demonstrar o quanto podemos ser maus sem que tenhamos consciência, graças a uma incapacidade de deixar que a realidade do outro, que o sentido por ele trazido, permeie nosso mundo. E isso nos remete ao quanto uma decisão judicial pode ser má, por não permitir que o sentido trazido pelas opiniões dos personagens envolvidos seja levado a construir, conjuntamente com a opinião do juiz, o sentido buscado pelo processo judicial. ${ }^{108}$

\subsection{Responsabilidade}

Em primeiro lugar, cumpre salientar que não se busca, aqui, discorrer sobre qualquer tipo de responsabilidade civil ou administrativa do juiz (e dos juristas em geral). ${ }^{109}$ Trata-se, sim, de uma responsabilidade ética, no sentido de uma ética da responsabilidade. ${ }^{110}$

105 ROVIELLO, Op. Cit., p.181.

106 CALAMANDREI, Piero. Elogio dei giudici da un avvocato. Firenze: Le Mennier, 1955, p.269 e ss. apud CAPELETTI, Op. Cit., p.93.

107 E boa parte do conteúdo do ponto 2.4, acima.

108 Cf. ANEXO I, infra.

109 Se essa é a intenção, sugere-se a leitura do texto de CAPELETTI, Op. Cit.

110 Cf. Supra. 
O primeiro dogma a ser afastado é a não-responsabilidade do juiz em razão da transferência ao momento legislativo. Já é aceito sem grande contestação que a atividade jurisdicional possui ao menos algum grau de criação de Direito, o que acaba por afastar essa fuga de assumir o compromisso com a função desempenhada. A legislação só é chamada a fundamentar as decisões quando lhe é conveniente como fundamento; caso contrário, há sempre um princípio (constitucional ou não mas quanto mais amplo melhor) que a sustente - ainda que contra legem. ${ }^{111}$

Se a legislação, por si só, já não mais pode servir como refúgio satisfatório ao juiz que queira 'lavar as mãos' (embora ainda busquem esse subterfúgio), Arendt nos ensina que a ideologia vem justamente ao encontro do desejo do humano de não se responsabilizar. O pensamento ideológico, que nos conforta com 'verdades' - heterônomas -, nos traz uma falsa noção de segurança em nossos atos. Procurou-se demonstrar, supra, como o pensamento arendtiano nega essa 'fuga', atribuindo responsabilidade ao indivíduo que, justamente porque cego pelo pensamento ideológico, comete males infinitos.
Evitar a ideologia, nos dias atuais, não é fácil. Até porque o próprio sistema jurídico, como um todo, o é. Ovídio Baptista nos apresenta um argumento que é relevante: mesmo a negação de um agir por parte do juiz pode ser ideológico (e normalmente o é). Não interferir é, por exemplo, justamente um dos maiores dogmas do liberalismo como já foi referido, em trecho de Baptista já citado em nota de rodapé, no início deste texto. ${ }^{12}$

Se tomarmos por base o pensamento arendtiano, a alternativa que temos para assumir a responsabilidade (já que não há como fugir dela) é precisamente a negação de uma busca de verdades - ou, o que é pior, da verdade. Estas seriam, ou a verdade posta e imposta pela ideologia, ou a verdade arbitrária do julgador. A solução estaria na admissão de que dispomos é de opiniões, visões de mundo, que constituem, em conjunto (e em perspectiva) o senso comum - o sentido da realidade compartilhada. A busca desse sentido com o outro é que legitima o papel do juiz em uma sociedade democrática, que se diz negar as maldades do totalitarismo e da arbitrariedade.

O processo deveria nortear sua busca, então, não pela verdade, mas

111A colocação só vem ao encontro de quem sustenta que somos, hoje, no Brasil, positivistas exacerbados, legalistas, como muitas vezes se ouve. A fundamentação das decisões, no entanto, embora muitas vezes se baseie apenas em um artigo de lei, em uma visão mais ampla se aproximaria mais do fenômeno descrito pelo Realismo Americano mais radical do que de um legalismo formal aplicado em todos os casos judiciais. Refere-se a isso porque os mesmos textos legais são utilizados para fundamentar decisões as mais diversas - e, por vezes, até opostas.

112 SILVA, Ovídio A. Baptista da. Processo e Ideologia, p.16. 
pelo debate de opiniões verdadeiras (em oposição a arbitrariedades subjetivas $\left.^{113}\right)$. Lembremos que as opiniões só tomam consistência na medida em que são vistas a partir de outros pontos de vista sobre o mesmo mundo. ${ }^{114}$ Note-se que se fala do mesmo mundo, e não do mundo criado por cada um, em sua existência solipsista ou individualista. Esse próprio 'mesmo mundo' é instituído, como já afirmado mais de uma vez acima, pelo próprio debate sobre ele.

Ou seja, ao adentrarmos nessa leitura, admitimos que a opinião do juiz (e, finalmente, sua decisão) só possui consistência na medida em que é submetida a debate. Essa seria a saída para uma sincera constituição de um mundo comum entre o julgador e os envolvidos - se alargando, tout court, à sociedade globalmente considerada. Como já enunciado acima, essa não perspectivação por outras opiniões reduz a decisão judicial (quando considerada por outros que não o próprio julgador) a uma verdade solipsista ou ideológica.

Esse debate, essa sincera troca de opiniões acerca do mesmo mundo (nem o jurídico, nem o real, mas o mundo constituído pelo sentido) é o que pode e o que deveria salvar a legitimidade do Judiciário enquanto fenômeno social e cultural (em oposição a arbitrário e ideológico). A constituição de sentido em conjunto pelos envolvidos é o que visa a garantir que a decisão faça sentido fora do contexto privado do juiz.

Nesse contexto, uma das formas de buscar a realização de tal ideal é, possivelmente, por meio da oralidade dos atos judiciais. Só pode haver verdadeiro debate na forma oral. O que há, em nosso processo - como já referido -, é a enunciação de versões. De uma parte, da outra, do juiz. Não há debate, não há troca, não há construção em conjunto do que quer que seja.

A nossa prática judicial vem caminhando no sentido contrário, embora recentes (e pequenas) reformas no sistema estejam buscando salvar a oralidade. Esse caminho ratificador da cultura dos escritos (e, conseqüentemente, da distância entre os sujeitos do processo) é uma falha grave. A parte não só não participa, como é irrelevante para a solução da lide. Mesmo por meio de seus advogados, seu ponto de vista, suas razões vêm podendo ser elegantemente ignorados. Se, em um passado recente, já muito se decidia que o magistrado não estava obrigado a examinar todos os argumentos das partes (além de as decisões só exporem o argumento vencedor, como bem ressaltou Ovídio Baptista ${ }^{115}$ ), recentemente se decide que o argumento das partes não precisa sequer ser considerado. ${ }^{116}$

113 Cf. Supra.

114 ROVIELLO, Op. Cit., p. 112; Cf. Supra.

115 Cf. Supra.

116 Cf. Anexo I. 
Note-se que esse afastamento, provocado pelo uso exacerbado da palavra escrita, entre o discurso e a realidade, entre a palavra e o que ela tem de potente, pode, também, ser causa de uma banalização do mal. Os sentidos dos atos praticados no foro não são vistos nem sentidos por quem os pratica e, sobretudo, refere-se aos funcionários públicos e juízes, pois advogados acabam por ter contato com seus clientes e vêem o impacto a eles causado na hora de lhes traduzir os segredos jurídicos contidos nos processos em comandos e limitações (e, por que não dizer, por vezes até humilhações).

Capeletti, citando Giuliani e Picardi, afirma: "a história demonstra (...) como é ilusório todo discurso sobre a responsabilidade judicial, quando o segredo cobre o momento da decisão." A solução da lide afasta-se da realidade quando tomada no silêncio de um gabinete, em isolamento. Afasta-se mais ainda quando ela é comunicada por intermédio do papel, de uma comunicação oficial, para, só então, ser transmitida pelo advogado à parte. $\mathrm{O}$ seu impacto, benéfico ou maléfico, é diacrônico, e do qual o julgador muitas vezes - ou na maioria das vezes - sequer tomará conhecimento (a não ser, quem sabe, por escrito, novamente via intermediários profissionais, quando das razões de algum dos infindáveis recursos que temos, e que sequer são para esse fim).

$\mathrm{O}$ verdadeiro debate de opiniões aqui proposto, como forma de legitimar o Judiciário e de garantir maior prestígio aos julgadores, passa por, no mínimo, levar ao debate as afirmações dos advogados $e$ a opinião do juiz, no curso do processo; no final, levar a debate a própria decisão, em frente aos interessados (diante das partes). Assim, o magistrado garantiria o contato da sua solução com a realidade, receberia um feedback imediato do que pretende decidir, construindo, democraticamente, o sentido da solução a ser adotada para a lide.

Capeletti se refere muitas vezes a um 'dever de prestar contas' por parte do juiz. ${ }^{117}$ Por esse prestar contas, no contexto deste trabalho, pode-se entender o levar em consideração a posição da sociedade - e, nisso, leia-se de ambas as partes - na busca pela solução do litígio. É um 'prestar contas do porquê da decisão' que, levado a cabo, é uma fundamentação e uma justificação sólidas e amplas. Nestas é que o julgador 'prestará contas' e mostrará por que a sua decisão faz sentido e - mais ainda - por que ele possui legitimidade para um papel tão relevante e delicado em uma sociedade democrática quanto o de juiz. A justificação (prestação de contas) se transfere das razões de si para o sentido que a decisão faz e deve fazer ao outro, à sociedade.

Há um último ponto a ser abordado com referência à responsabilidade, e que diz respeito à avaliação que se faz da decisão. A partir da premissa apresentada acima, no ponto 2.5 , de que não podemos ser os juízes éticos de 
nosso próprio caso (ou, leia-se, da nossa própria conduta), encontramos mais uma questão: o magistrado não pode decidir pela correção ou justiça da sua própria decisão.

Essa conclusão não leva a nenhum radicalismo a proposta aqui levantada. Pelo contrário: corrobora com a afirmação de que a decisão que o juiz fundamenta a partir das suas próprias convicções de correção e justeza não está adequadamente justificada. $\mathrm{O}$ argumento, corrente em nosso meio jurídico, de que o juiz deve decidir baseado em suas próprias convicções não se sustenta - não só por todos os argumentos apresentados até agora, mas também porque não lhe é eticamente possível avaliar a própria ação (o ato de julgar).

Essa deveria ser a função dos tribunais. Tem-se considerado um tanto ineficiente nossa solução de 'duplo grau de jurisdição', que não faz mais que desvalorizar o primeiro deles. A matéria (segundo, inclusive, princípio processual) é 'devolvida', para que seja novamente decidida. $\mathrm{O}$ que acontece, via de regra, é uma transferência dos problemas encontrados em primeira instância, no que diz respeito à função jurisdicional, com o agravamento de alguns deles (como a distância em relação aos fatos, às partes e às testemunhas, a ainda maior falta de oralidade e debate, dentre outros ${ }^{118}$ ).

Inserto no contexto filosófico que se propõe, o que deveria haver seria uma 'jurisdição de segundo grau', e não um 'segundo grau de jurisdição'. A função daquela seria, não decidir novamente a lide, mas avaliar a decisão do juiz de primeiro grau. Valorizar-lhe, e não tomarlhe boa parte do mesmo poder. E essa avaliação, novamente, não deveria ser meramente técnico-jurídica (ou talvez nem o deveria ser), mas principalmente ética, inserida na idéia de uma 'ética da responsabilidade' arendtiana.

Teríamos, assim, três desembargadores com o papel de debater, entre si e, também e principalmente, com as partes (representadas por seus advogados), as quais simbolizam, também, o restante da sociedade, o sentido que a decisão de primeiro grau faz ou deixa de fazer no mundo constituído pelas opiniões mesmas que sobre ele se manifestam. É importante

118 Há ainda vários outros problemas atinentes especificamente à jurisdição de segunda instância como praticada nos sistemas de Direito Continental, como, por exemplo, a falta de exposição clara das posições divergentes no tribunal, a falta de debate entre os desembargadores - pois, nos acórdãos, razões e argumentos são reduzidos a números (votos), etc. Para essa argumentação, ver MERRYMAN, La Tradición Jurídica...., p.71 et passim; sobre a desvalorização do juiz de primeiro grau, sobrevalorização dos recursos e burocratização da magistratura, ver CAPELETTI, Op. Cit., p.48. Sem falar na redução da quase totalidade dos julgamentos de nossos colegiados, sobretudo de segundo grau, a decisões supostamente unânimes (ou que assim aparecem). Faz-se referência, por oportuno, a casos em que são tomadas decisões contraditórias ou até opostas, todas unânimes, em Acórdãos proferidos na mesma sessão de julgamento, mas relatados por diferentes Desembargadores. 
frisar que esse debate discursivo não é sobre o mundo, mas é a própria instituição de um mundo compartilhado!

A função da revisão das decisões não deveria ser somente avaliar a capacidade técnica do juiz (pois o Direito não é meramente uma técnica), nem mesmo questionar suas convicções íntimas (o que seria indesejável e deveras autoritário), ou substituí-las por outras (o que seria adiar o problema a outra instância, e assim por diante). Deveria ser simplesmente debater, democraticamente, se a decisão faz ou não sentido no mundo em que nos encontramos, no qual dependemos do outro para o sentido da nossa própria existência.

\section{CONCLUSÃO}

[Capeletti, citando Merryman:] 'Os juízes exercitam um poder. Onde há poder deve haver responsabilidade: em uma sociedade organizada racionalmente, haverá uma relação diretamente proporcional entre poder e responsabilidade.' [...] O poder [com a palavra, Capeletti], é bem sabido, freqüentemente cresce sem o correspondente crescimento da responsabilidade. In rerum natura, portanto, não existe correlação necessária entre poder e responsabilidade, no sentido indicado por Merryman. Mas um poder não sujeito a prestar contas representa uma patologia, ou seja, isto que Merryman apelida, com expressão que oculta um pouco seu conteúdo ideológico, de falta de 'organização racional' mas que, em ciência política, se pode sim-plesmente rotular de autoritarismo e, na sua expressão extrema, de tirania. [...] [Por fim, cita Trocker:] 'um poder sem responsabilidade é incompatível com um sistema democrático." 119

Uma intenção secundária deste texto foi tentar demonstrar por que não seria democrático um poder (Judiciário) sem responsabilidade. Pede-se desculpas, apenas, por eventual distorção da acepção empreendida por Capeletti (e, possivelmente, antes por Merryman) em sua colocação, para trazê-la à tradição arendtiana. Mas tal interpretação foi tomada sem remorsos, pois, como as opiniões tomam consistência quando vistas a partir de outras, assim também as perspectivas de cunho filosófico, que não se opõem, mas se complementam e se dão, mutuamente, sentido.

Procurou-se demonstrar que a responsabilidade pela função jurisdicional não tem apenas relação com legalidade: com legitimidade formal, com responsabilidade civil, penal ou administrativa (disciplinar). Certamente tem alguma conexão com o que Capeletti denominou de "responsabilidade social" 120 , sobretudo no que diz respeito à questão de dever ser a responsabilidade vista, não em função do juiz ou da magistratura, nem em função de uma

119 CAPELETTI, Op. Cit., p.18.

120 Ibidem, passim. 
entidade abstrata de poder (como o 'estado' ou o 'soberano'), mas em função dos usuários: da coletividade. ${ }^{121}$

Contudo, não é só isso. Como se tentou argumentar, a responsabilidade não é suficientemente exercida quando o jurista se recolhe em seu mundo e, após, apresenta (leia-se impõe) uma 'solução' jurídica para o caso. A ética envolvida com a atividade jurisdicional em uma concepção democrática deve perpassar pela comunidade, ser construída e instituída junto com ela. Não basta que a criação de leis seja democrática (e quanto a isso já há suficientes dúvidas) se a aplicação (leia-se: construção do sentido jurídico quando do julgamento) é autoritária ou ideológica.

Já o ônus primário ao texto imposto foi o de procurar demonstrar que tal concepção parte, necessariamente, do abandono dos juízos de certeza, da busca pela 'verdade', do dogmatismo. Quando envolvemos, sinceramente, a convicção do outro, a certeza se dilui. Não há univocidade de sentido, que é constituído livremente. Roviello chama a isso de 'paradoxo da modernidade':

[A] diferença entre o sentido e o não-
sentido, o legítimo e o ilegítimo, é ela
própria uma diferença dotada de sen-
tido, isto é, fundadora da humanidade
do homem e da sociedade humana. [...]
[S]ão os homens que estabelecem livre-
mente esses limites, de que são os homens
que instituem livremente uma comuni- dade assente no sentido dessa diferença entre o sentido e o não-sentido. ${ }^{122}$

Assumir que a busca do jurista é uma busca do sentido (e não uma descrição do mundo natural ou uma verdade metafísica - os dois extremos) o põe em uma situação extremamente difícil. Como Arendt mesma afirmou, a ideologia vem justamente ao encontro desse desejo humano de não ter que se responsabilizar. ${ }^{123}$ Tanto a heteronomia quanto a autonomia solipsista levam o indivíduo a se afastar do sentido conferido ao mundo que divide com os outros homens. Aquele que não lida com a tensão constante de uma realidade que se institui livremente pelo sentindo, em conjunto com os outros (e não num ou noutro extremo), é o que está sujeito a cometer os maiores males.

Todavia, um dos pontos centrais de trazer à tona o pensamento de Hannah Arendt no âmbito da jurisdição é fazer ver que esse 'lavar as mãos', sob as muitas máscaras que é apresentado, pode ser a origem dos piores males. A proposta apresentada visa a afastar o mal banalizado que possa ser produzido por um Judiciário ideológico (ainda que de ideologia conservadora e liberal, pouco importa), autoritário, arbitrário ou, simplesmente, burocratizado ou alienado; mas, sobretudo, por um Judiciário que sequer escuta honestamente àqueles a quem deve e a quem irá julgar.

121 Ibidem, p.91.

122 ROVIELLO, Op. Cit., p.183.

123 Cf. Supra. Ver também FOUCAULT, Op. Cit., passim. 


\section{REFERÊNCIAS}

ARENDT, Hannah. A Condição Humana. Trad. Roberto Raposo. Rio de Janeiro: Forense Universitária, 2005. . Hannah. A Vida do Espírito: $o$ pensar, o querer, o julgar. Tradução: Antônio Abranches e Helena Martins. Rio de Janeiro: Relume Dumará, 2000.

Responsabilidade e Julgamento. Trad. Rosaura Eichenberg. São Paulo: Companhia das Letras, 2004. . Verdade e Política. Trad. Manuel Alberto. Lisboa: Relógio d'Água Editores, 1995.

ARISTÓTELES. Política. São Paulo: Martin Claret, 2005.

CAPELETTI, Mauro. Juizes Irresponsáveis? Tradução e Revisão: Carlos Alberto Alvaro de Oliveira. Porto Alegre: Fabris, 1989.

CARDOZO, Benjamin N. A Natureza do Processo Judicial. São Paulo: Martins Fontes, 2004.

FOUCAULT, Michel. A Ordem do Discurso. Tradução: Laura Fraga de Almeida Sampaio. São Paulo: Loyola, 2005.

\section{ANEXO I}

Traz-se neste anexo uma decisão proferida em acórdão recente, com a finalidade de ilustrar - em termos práticos - o que foi amplamente debatido no corpo deste trabalho.

Deixa-se as conclusões que advêm da mesma ao sabor do próprio intérprete.
MATEUCCI, Nicola. Organización del Poder y Libertad: historia del constitucionalismo moderno. Madrid: Trotta, 1998.

MERRYMAN, John. La Tradición Jurídica Romano-Canônica. México: Fondo de Cultura Económica, 1971.

ROVIELLO Anne-Marie. Senso Comum e Modernidade em Hannah Arendt. Trad. Bénédicte Houart e João Felipe Marques. Lisboa: Instituto Piaget, 1987.

SILVA, Ovídio A. Baptista da. Processo e Ideologia. Rio de Janeiro: Forense, 2006.

Fundamentação das Sentenças como Garantia Constitucional, in Revista do Instituto de Hermenêutica Jurídica, v.1, n.4. Porto Alegre: Instituto de Hermenêutica Jurídica, 2006, p.323-352. . Jurisdição e Execução na tradição romano-canônica. São Paulo: Editora Revista dos Tribunais, 1996.

SOUKI, Nádia. Hannah Arendt e a Banalidade do Mal. Belo Horizonte: Editora UFMG, 1998.

DATA: 28/06/2006 CADERNO 1 DA UNIAO PAG. N ${ }^{\circ} 419$.

TRIBUNAL REGIONALFEDERALDA $3^{\mathrm{a}} \mathrm{REGIÃO}$

SUBSECRETARIA DA QUARTA TURMA

PROC. : 2003.03.00.065491-6AG 191346 ORIG : $9107239106 / S P E M B A R G O S D E$ DECLARAÇÃO EM AGRAVO DE INSTRUMENTOAGRTE : EDITORA 
GLOBO S/AADV : DANIEL SANTOS DE MELO GUIMARÃES AGRDO: União Federal (FAZENDANACIONAL) ADV: ELYADIR F BORGES E MIRIAM APARECIDA P DA SILVA PARTE A: NETCOM COMUNICAÇÕES S/A ORIGEM: JUÍZO FEDERAL DA $8^{\mathrm{a}}$ VARA SÃO PAULO Sec Jud SP REL ATOR:DES. FED.FÁBIO PRIETO DE SOUZA/QUARTATURMA

EMENTA - EMBARGOS DE DECLARAÇÃO - ALEGAÇÃO DE OMISSÃO: INEXISTÊNCIA PREQUESTIONAMENTO REJEIÇÃO.

1) O Poder Judiciário, pela iniciativa das partes, está vinculado a decidir a lide, em regra, nos termos do pedido. Mas a decisão fica sujeita a qualquer fundamento jurídico. 2) Na solução da causa, a adoção de fundamento jurídico diverso do exposto pela parte não é omissão. É divergência de intelecção na solução da lide, circunstância desqualificadora da interposição de embargos de declaração. 3) A Constituição Federal não fez opção estilística, na imposição do requisito da fundamentação das decisões. Esta pode ser laudatória ou sucinta. Deve ser, tão-só, pertinente e suficiente. 4) Os requisitos previstos no artigo 535, do Código de Processo Civil, devem ser observados nos embargos de declaração destinados ao prequestionamento. 5) Embargos rejeitados. ACÓRDÃO Vistos, relatados e discutidos estes autos, em que são partes as acima indicadas, ACORDAM os Desembargadores Federais da Quarta Turma do Tribunal Regional Federal da $3^{\text {a }}$ Região, na conformidade da ata do julgamento, por unanimidade de votos, em rejeitar os embargos de declaração, nos termos do relatório e voto do Desembargador Federal Relator, que fazem parte integrante do presente acórdão. São Paulo, 15 de março de 2006 (grifamos). 
